\title{
Absenteeism in Slovenian railways \\ - comparison between different work groups
}

\author{
Martin Vrašec', Matej Voglar \\ I Slovenian Railways, Ltd, Kolodvorska II, I506 Ljubljana \\ 2 University of Primorska, Faculty of Health Sciences, Polje 42, 6310 Izola \\ martin.vrasec@slo-zeleznice.si; matej.voglar@fvz.upr.si
}

\begin{abstract}
Introduction: In the working environment there are several (even negative) factors which can affect employees and the consequence is absenteeism. The most often causes of absenteeism in Slovenian Railways Group are musculoskeletal problems, nonworking infections and injuries, and mental and behavioral disturbances. Methods: We observed the percent of absenteeism between four work groups, of which two groups were regular work schedule and two groups were shift-work schedule. The absenteeism was observed between years 2007 and 2015. Regular work schedule employees were office workers and railway infrastructure maintenance workers. Shift-work schedule employees were train drivers and railway wagon inspectors. Results: Using 2-way ANOVA we found the greatest percent of absenteeism in railway infrastructure maintenance workers $(6,38 \% \pm 0,95 \%)$, followed by train drivers $(4,49 \% \pm 1,39 \%)$ office workers $(4,23 \% \pm 0,58 \%)$ and railway wagon inspectors $(3,28 \% \pm 0,62 \%)$. Conclusion: Because we did not have available data on the causes of absenteeism, we can about them only assume on the basis of knowledge of the working environment. In the next survey, we will ask employees about the causes of absenteeism and on the basis of the results we will produce guidelines and recommendations for preventive action.

Key words: percent of absenteeism, railway infrastructure maintenance workers, train drivers, office workers, railway wagon inspectors.
\end{abstract}

I

n working environment, the workers are influenced by several physiological and psychological risk factors. When workers are exposed to those factors for a longer period of time the consequence can be absenteeism. Three main causes for increased absenteeism are I.) incorrect posture and incorrect manipulation with objects, II.) increased body mass and III.) physical inactivity 
(Albreht, 2016). Epidemiological research has been providing information on causality of infectious diseases and causality of some chronic diseases thus influencing occupational health and safety. Furthermore, epidemiology can explain causality of absenteeism. Absenteeism is expressed in percentage therefore giving the average fraction of lost working days per person (NIJZ, 2016). Between years 2007 and 2015 the absenteeism in the Slovenian Railways Group was higher in comparison with absenteeism in the Republic of Slovenia (Figure 1) therefore we wanted to examine the absenteeism by different occupational subgroups. In our research, we compared absenteeism between four groups of workers of Slovenian Railway Group. The data was acquired from annual workers health reports which are every year prepared for the previous year. Current annual reports represent just percent of absenteeism but not the detailed information about causality of absenteeism.

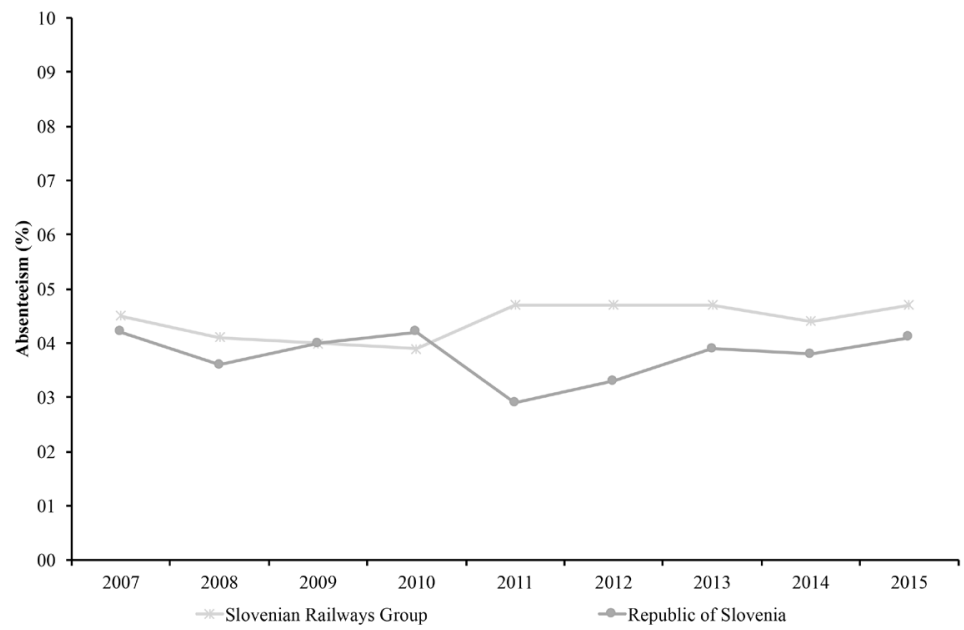

Figure 1: Graphically represented percent of absenteeism between Slovenian Railways Group and Republic of Slovenia.

Workers from the observed groups were railway maintenance workers, office workers, train drivers and railway wagon inspectors. Railway maintenance workers and office workers have regular work schedule, while train drivers and wagon inspectors work in shift-work schedule. The other difference between groups is the dynamic of their work with railway maintenance and wagon inspectors having dynamic work while office workers and train drivers have predominantly sedentary work. The health-risk factors in the maintenance workers group are lifting and moving heavy objects, work in the forced posture, and exposure to weather conditions. The health-risk factors in the office workers group include prolonged sitting (often in the forced posture) and stress. Train drivers work 8-12 hours and are exposed to prolonged sitting, forced posture and whole-body vibrations, accompanied by stress, exposure to electro-magnetic fields, sleep deprivation, eating disorders and other (Vrašec, 2015). Wag- 
on inspectors also work 8-12 hours. They work outside therefore the health-risk factors in this group are exposure to different weather conditions, danger of falls, and asymmetrical posture at work.

On the other hand train drivers and wagon inspectors are part of executive railway workers. Executive railway workers are taking an active part in the railway traffic therefore must be at the good health, free of hearing or eyesight troubles, cardiovascular diseases, with settled blood pressure and other. Also, before starting a career, the train driver must perform an ultrasound or ECG which is required in the guidelines of the international association of the railway medical services (van Dijk, Govaart \& Voumard, 2007).

The goal of our study was to assess if there are statistically significant differences in the absenteeism between these different groups of railway workers. Furthermore the potential effects of sedentary work and shift work on absenteeism were assessed. We hypothesized that there will be significant difference between different occupations and that shift work and physical work will result in more absenteeism.

\section{Methods}

We observed the incidence among four occupational groups of the Slovenian Railways Group, i.e. office workers (regular work schedule, sedentary), maintenance workers (regular work schedule, dynamic, heavy duty), train drivers (shift-work schedule, prolonged sitting) and wagon inspectors (shift-work schedule, dynamic duty). We acquired the data from annual reports on workers' health in the Slovenian Railways Group between years 2007 and 2015. Only the data about absenteeism was included. The data for the nursing or attendance were excluded (E8 by the ICD-10). The average number of employees in the observed period was 1590 in the office workers group, 390 in the railway maintenance group, 960 in the train drivers group and 206 in the wagon inspectors group (table 1). We didn't find the data for the age, gender and other in the annual reports.

SPSS version 20 (SPSS Statistics, IBM, New York, ZDA) has been used for the analyses. One-way analysis of variance (1-way ANOVA) was conducted in order to assess the differences between occupational subgroups (dynamic regular schedule, sitting regular schedule, sitting shift-work schedule, dynamic shift-work schedule). Two-way analysis of variance (2-way ANOVA) was conducted in order to examine the effect of the work schedule and the effect of the dynamics at work (physically active vs. sedentary) and the interaction effect (schedule (2) x dynamic (2)). Statistical significance was set at the $\mathrm{p}<0,05$. 
Table 1: The number of employees by the occupation.

\begin{tabular}{|c|c|c|c|c|c|}
\hline & \multirow[b]{2}{*}{ Year } & \multicolumn{4}{|c|}{ Occupation } \\
\hline & & $\begin{array}{c}\text { Maintenance } \\
\text { workers }\end{array}$ & Office workers & Train drivers & Wagon inspectors \\
\hline \multirow{9}{*}{$\begin{array}{l}\text { The num- } \\
\text { ber of em- } \\
\text { ployees }\end{array}$} & 2007 & 473 & 1670 & 1038 & 237 \\
\hline & 2008 & 481 & 1708 & 1072 & 228 \\
\hline & 2009 & 443 & 1735 & 1090 & 245 \\
\hline & 2010 & 416 & 1553 & 958 & 193 \\
\hline & 2011 & 378 & 1387 & 917 & 191 \\
\hline & 2012 & 334 & 1371 & 892 & 195 \\
\hline & 2013 & 315 & 1714 & 880 & 192 \\
\hline & 2014 & 344 & 1417 & 922 & 190 \\
\hline & 2015 & 322 & 1757 & 871 & 180 \\
\hline \multicolumn{2}{|c|}{ Average 2007-2015 } & 390 & 1590 & 960 & 206 \\
\hline
\end{tabular}

Results

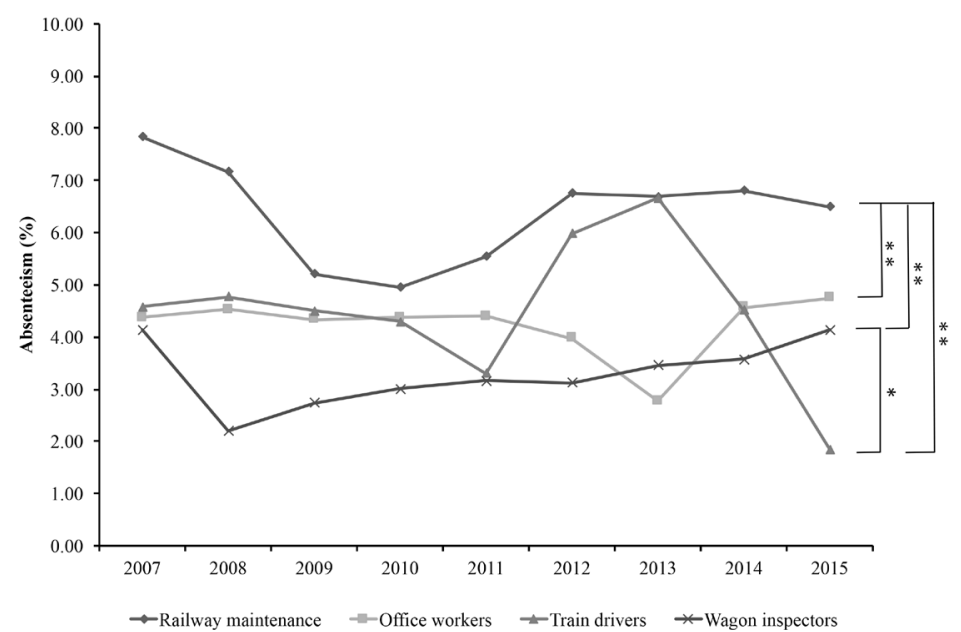

Figure 2: Graphically represented percent of absenteeism among the observed groups.

${ }^{*} \mathbf{p}<0,050$; ${ }^{* *} \mathbf{p}<0,001$

Using one-way ANOVA we found significant differences between groups. Maintenance workers have the highest percent of absenteeism $(6,38 \% \pm 0,95 \%)$ which is significantly higher when compared to office workers $(4,23 \% \pm 0,58 \%$; $\mathrm{p}<\mathrm{0}, 001, \mathrm{~F}=2,152)$, train drivers $(4,49 \% \pm 1,39 \% ; \mathrm{p}<0,001, \mathrm{~F}=1,887)$ and wagon inspectors $(3,28 \% \pm 0,62 \% ; \mathrm{p}<0,001, \mathrm{~F}=3,102)$. Significant difference was also found between train drivers and wagon inspectors $(\mathrm{p}<0,050, \mathrm{~F}=1,214)$. 
Between other groups we didn't find significant differences. Figure 2 represents data graphically.

Using two-way ANOVA we first tested the interaction effect between the effect of the work schedule and the effect of the dynamic and the differences by each factor. Comparing by factor dynamic (sedentary vs. physically active) did not show significant differences $(\mathrm{p}=0,147, \mathrm{~F}=2,208)$. On the other hand, there were significant differences found when comparing by factor work schedule (regular vs. shift-work) ( $\mathrm{p}<\mathrm{0}, 001, \mathrm{~F}=20,217)$. Also we found the significant in-

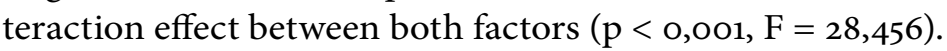

\section{Discussion}

We found the highest percent of absenteeism in the railway maintenance group (dynamic, heavy duty, regular schedule) and the lowest percent of absenteeism in the wagon inspectors group (dynamic, shift-work schedule). Train drivers (sitting, shift-work schedule) had lower percent of absenteeism compared with maintenance workers and higher percent compared with office workers (sitting, regular schedule). The data shows common percent of absenteeism (without nursing or attendance) and doesn't include causalities for the absenteeism. By the factor of dynamics (sedentary vs. physically active) we didn't find significant differences while differences were found by the factor work schedule (regular vs. shift-work), surprisingly showing lower rate of absenteeism in workers working in shifts. We have also found the significant interaction effect between both factors indicating that combination of shift work schedule and static work or combination of regular work schedule and heavy duty work can cause higher rate of absenteeism. Moreover, we can assume that heavy duty work has stronger impact on absenteeism than shift work.

We acquired information about causalities by National Institute of Public Health. Most often causalities for absenteeism in the Slovenian Railways Group between years 2007-2015 were musculoskeletal problems, nonworking infections and injuries, and mental and behavioral disturbances, followed by work-related injuries and respiratory diseases. The average number of work-related injuries in Slovenian Railways Group was 22 per 1000 employees, which is almost half of that what found Gauchard et al. (2003) in the large French railway company ( $\sim$ O work-related injuries per 1000 employees). Gauchard et al. (2003) found that more than $15 \%$ of injuries were due to falls. Falls were most freequent in train drivers, maintenance workers and production operators (Gauchard et al., 2003; Chau et al., 2004). Mental and behavioral disorders were often cause for absenteeism in Chinese executive railway workers (Zhang et al., 2016) and in contrast with our data, they were more comon than musculoskeletal diseases. Compared with our survey in which we observed all employees, Zhang et al. (2016) included just executive railway workers which could contribute to the observed differences. Mental and behavioral disorders are often related with increased workload and shift work, which can cause sleep disturbances and changes in circadian rhythm (Jeon et al., 2013). Furthermore, 
it can cause fatigue, which can lead to general dissatisfaction. Another stress factors specific for train drivers are accidents with road or railway vehicles and run overs, which often have fatal consequences. Following accidents posttraumatic stress disorder is often seen in train drivers (Doroga \& Baban, 2013; Jeon et al., 2013), therefore we have consultants for the first psycho-social aid in the Slovenian Railway Group. It should be noted that physically active employees and those with healthy (settled) lifestyle are more successful in coping stress, PTSD and other risk factors.

The highest percent of absenteeism was found in railway infrastructure maintenance workers. We assume that the most probable cause for the absenteeism in this group were musculoskeletal diseases and work-related injuries. Furthermore, lower education and lower financial income are known to be related with unhealthy habits. In comparison, the office workers have higher incomes and also it is required at middle school education or higher for office position. The risk factors in office workers are prolonged sitting in forced position and stress thus we assume that causes for the absenteeism are musculoskeletal diseases due to static postures followed by mental and behavioral disorder due to work related stress. In support to this assumption is the fact that office workers are predominantly women and reports show that women are more often absent due to mental and behavioral disorders compared with male colleagues.

The second highest percent of absenteeism was found in train drivers. Train drivers work in shift-work schedule which has been shown to be a risk factor for sleep disorders, metabolic syndrome and heart diseases (Costa, 2010). Other important risk factors are prolonged sitting in restricted position, exposure to whole body vibrations, electromagnetic field and noise. Prolonged sitting and exposure to whole body vibrations can cause changes in neuromuscular functions of the trunk and increase the risk of low back pain (Vrašec, 2015). However, based on results of previous survey, the train drivers are familiar with guidelines for preventive action at work and in a leisure time (Vrašec, 2015). Furthermore prolonged exposure to noise can cause hear loss therefore train drivers are equipped with active silencers. Exposure to electromagnetic fields and engine exhaust were recognized as risk factor for cancer development. According to aforementioned risk factors and consequences, we assume that train drivers are mostly at risk for developing musculoskeletal disorders and metabolism related problems.

The lowest percent of absenteeism was found in wagon inspectors, who also work in shifts. Wagon inspectors are working outside, exposed to all weather conditions. During 12-hour shift they are mostly walking due to technical examination of the train, testing the break system of the train and other. The path by the track, where wagon inspector walk during work, must be well hardened and well-lighted in all weather conditions. Due to maintenance work or some other unpredictable factor there is a possibility of unpredicted obstacles on the path. During his work the wagon inspector does not watch the path but mostly the train and consequently it can cause slips or falls. Despite mentioned fac- 
tors we found lowest percent of absenteeism in this group therefore we can assume that regular and moderate physical activity, even at work, can have an important role in health care. Unfortunately, the data on the causes of absenteeism were not available by separate groups, therefore we can only speculate on the predominant causes based on the knowledge of the working environment. However, more objective validation is necessary therefore we will perform additional surveys.

\section{Conclusion}

In order to assure better overview on causalities for absenteeism, the renewal of the human resources office information system will be suggested. Renewed system should enable evidence on absenteeism not only by duration but also by causes separately by different occupations. Based on these data we could prepare guidelines and recommendations for safer work and for the preventive action at work and leisure time. All employees, especially executive railway workers, are well informed about safety at work already before starting the career. Despite this their compliance with recommendations is questionable. In addition to renewal of the human recourses office information system a survey should be performed, in which employees could write their most often diseases or disorders. Based on the results of the survey recommendations and guidelines for the preventive action at work and in a leisure time could be suggested immediately. Based on the results of this study, we believe that railway infrastructure maintenance workers should be the first to be informed with guidelines for the preventive action. This will be implemented as a part of an occupational health promotion which is not just a legal obligation but provides long term benefit for the company and personnel. As Podjed,( 2014) has been shown, we can expect a return of 2,4-4,8 euros for every 1 euro invested in health promotion and that absenteeism decreases $35 \%$ in employees who visit occupational health promotion programs.

\section{References}

ALBREHT, T., 2016. Epidemiologija in ergoepidemiologija - Splošna epidemiologija. Prosojnice in zapiski predavanj pri predmetu Epidemiologija in ergoepidemiologija, podiplomski magistrski študijski program Aplikativna kineziologija. Fakulteta za matematiko, naravoslovje in informacijske tehnologije. Univerza na Primorskem.

CHAU, N., MUR, J.M., TOURON, C., BENAMGHAR, L., and DEHAENE, D., 2004. Correlates of occupational injuries for various jobs in railway workers: a case-control study. Journal of Occupational Health, 46(4), 272-280.

COSTA, G., 2010. Shift work and health: current problems and preventive actions. Saf Health Work, 1(2), 112-123. 
DOROGA, C., and BĂBAN, A., 2013. Traumatic exposure and posttraumatic symptoms for train drivers involved in railway incidents. Clujul Medical (1957), 86(2), 144-149.

GAUCHARD, G.C., CHAU, N., TOURON, C., BENAMGHAR, L., DEHAENE, D., PERRIN, P., and MUR, J.M., 2003. Individual characteristics in occupational accidents due to imbalance: a case-control study of the employees of a railway company. Occupational and Environmental Medicine, 60(5), 330-335.

JEON, H.J., KIM, J.H., KIM, B.N., PARK, S.J., FAVA, M., MISCHOULON, D., ... LEE, D., 2014. Sleep quality, posttraumatic stress, depression, and human errors in train drivers: a population-based nationwide study in South Korea. Sleep, 37(12), 1969-1975. https://doi.org/10.5665/sleep.4252

NIJZ - Nacionalni inštitut za javno zdravje, 2016. Pridobljeno na spletnem naslovu http://www.nijz.si/sl/podatki/bolniski-stalez dne 20.12.2016.

PODJED, K., 2014. Proaktivni pristop k promociji zdravja na delovnem mestu. Ekonomska demokracija. Pridobljeno 14.3.2016 na spletnem naslovu www.produktivnost.si/wp-content/uploads/2014/og/Proaktivni-pristop-k-promociji-zdravja-na-delovnem-mestu-Ekonomska-demokracija-avg-2014.pdf

VAN DIJK, J., GOVAARTS, J., and VOUMARD, P.A., 2007. Vocational rehabilitation of locomotive engineers with ischaemic heart disease. Occupational Medicine (Oxford, England), 57(2), 131-136. https://doi.org/10.1093/ occmed/kqli58

VRAŠEC, M. (2015). Vpliv delovnega mesta strojevodje vlaka na živčno-mišične funkcije trupa $v$ kontekstu tveganja za pojav bolečine $v$ spodnjem delu hrbta. Diplomska naloga. Fakulteta za matematiko, naravoslovje in informacijske tehnologije. Univerza na Primorskem. Koper.

ZHANG, X., CHEN, G., XU, F., ZHOU, K., and ZHUANG, G., 2016. Health-Related Quality of Life and Associated Factors of Frontline Railway Workers: A Cross-Sectional Survey in the Ankang Area, Shaanxi Province, China. International Journal of Environmental Research and Public Health, 13(12). https://doi.org/10.339o/ijerph13121192 